\title{
Creative Use of Second Language Theories and Creative Language Learning: Some Considerations
}

\author{
Ali Ata Alkhaldi ${ }^{*}$ Hanane Benali Taouis \\ Department of Liberal Arts, American University of the Middle East, Kuwait
}

Received October 30, 2020; Revised December 15, 2020; Accepted December 30, 2020

\section{Cite This Paper in the following Citation Styles}

(a): [1] Ali Ata Alkhaldi, Hanane Benali Taouis , "Creative Use of Second Language Theories and Creative Language Learning: Some Considerations," Universal Journal of Educational Research, Vol. 8, No. 12B, pp. 8536 - 8543, 2020. DOI: 10.13189/ujer.2020.082664.

(b): Ali Ata Alkhaldi, Hanane Benali Taouis (2020). Creative Use of Second Language Theories and Creative Language Learning: Some Considerations. Universal Journal of Educational Research, 8(12B), 8536 - 8543. DOI: 10.13189/ujer.2020.082664.

Copyright $\odot 2020$ by authors, all rights reserved. Authors agree that this article remains permanently open access under the terms of the Creative Commons Attribution License 4.0 International License

\begin{abstract}
Despite potential barriers to developing creativity in English language teaching, developing the creativity of learners has many benefits for learning the language and for developing broader learning objectives, values and attitudes (Read, 2015). Second language theories are directly or indirectly embedded in the activities of the textbooks. However, textbooks do not encourage deep creative thinking skills (Alkhaldi \& Oshchepkova, 2018). Therefore, this paper critically analyses the creative use of second language theories in an interactive learning environment based on the related literature in an attempt to foster creativity and achieve durable language learning. It enumerates the major components of successful language learning as well-designed textbooks, effective teachers, and active learners. Language theories and activities are useless if the aforementioned major components are not used together in a creative way. Furthermore, the researchers have critically analyzed other variables in this study such as learning styles, motivation, teaching and learning approach, creativity, and creative classroom interaction. This study recommends that textbook writers should include interesting activities that represent effective language theories, Foreign Language (FL) teachers should have professional development training on how to adapt and teach the language activities professionally, and the learners should be initiative and creative to master the language autonomously.
\end{abstract}

Keywords Creativity, Language Theories, Textbooks, Teachers, Learners

\section{Introduction}

"It is now accepted that, from the second half of the last century, emphasis on acquiring English language skills has been gathering momentum - there is a growing demand for English medium schools and universities in most countries" (Hann, Timmis, Alkhaldi, Davies, Troncoso \& Yi, 2014, p.2). The English language is widely used for a variety of reasons such as educational, intellectual, medical, commercial, political, and cultural purposes (McKay, 2002). Therefore, most of the world uses English to meet their needs and achieve their local and international success. The processes of economic and social globalization, notably, have made the English language use significant as it is an international means of communication (Alptekin, 2002).

Despite the fact that English is widely used in many countries, obstacles remain for mastering English appropriately. It is argued that there are various reasons for such weak performance, such as commercial textbooks, language theories misuse or their ineffectiveness, and the mismatch between theory and practice (Saraceni, 2003 \& Alkhaldi, 2014, 2019b). To overcome these obstacles, it is essential to analyze all important elements that take part in the education process: textbooks, teachers, learners including other related key variables such as learning styles, motivation, teaching and learning approach, creativity, and creative classroom interaction. 
Language is implicated in daily lives, so there are a lot of activities which are based on language theories (Cook, 2003). Furthermore, the effectiveness of theories relies on their effectiveness in practice (Abd Samad, 2003). As a result, effective theories in practice can facilitate the learning process effectively (Alkhaldi, 2014), especially if they are used creatively in the classroom. Tomlinson (2015) argues that fostering creativity of the learner is a vital role for teachers as it develops other essential skills for learning, notably critical thinking, problem-solving as well as boosting confidence. When learning is creative, learners engage more cognitively with the language and are able to use it more effectively. Tomlinson also noted that when teachers are creative, learners are creative too.

Likewise Read (2015) argues for the benefits of creativity in the classroom. She points out that young learners who learn English as a foreign language may have limited exposure to the language in reality; however, there is a wealth of creative potential in the classroom. She maintains that integrating creativity early in the language classroom greatly impacts the learner's ability to learn the language. She enumerates other significant skills which are enhanced as a result of creative activity in language learning, notably, increased motivation, enjoyment, patience, resourcefulness, divergent thinking, sense of success and learner autonomy. Therefore, a greater focus should be on creative teaching and learning English as a FL in the classrooms. Specifically, consideration should be given to the three major components in the language classroom to achieve creativity of using language theories and effectiveness of language learning: the textbooks, teachers, and learners. Therefore, the researchers critically analyze the creative role of these components.

\section{The Textbook}

The textbook is essential because it "fulfils a need, a purpose, it performs a function, conveys meaning.... language and coursebooks do not exist in a vacuum - they exist for and are shaped by a purpose within a particular context of use, culture and ideology" (Wala, 2003, p.60). In other words, it does not exist in isolation (Mukundan, 2006). However, publishers of global textbooks usually try to achieve commercial benefits (Dat, 2006) as their main goal is to achieve financial success (Richards, 2001). Such textbooks are used in many countries for teaching and learning English as a FL. Many teachers depend on the textbook to provide the activities in the classroom and most textbooks lack activities that foster creativity (Tomlinson \& Masuhara, 2013). Therefore, the teachers and learners should utilize the textbooks and their activities for creative use of the language. Tomlinson (2015) argues that the textbook is to be considered as a tool to nurture the teachers' creativity as they can adapt the materials rather than follow the book rigidly. One method to stimulate creativity is to facilitate students' personal responses rather than expecting a uniform answer.

Using the textbook in the classroom for teaching and learning English as a FL has numerous advantages. Notably, the textbook serves as a map (e.g., Richards, 2001; McGrath, 2002; Timmis, Mukundan, \& Alkhaldi 2009). It provides directions to guide the teaching and learning process in all schools in the same country (Crawford, 2002). The textbook provides both teachers and learners with content and theories which are embedded in the language activities to achieve the purpose of using them, and this shapes what may precisely happen inside the classroom (Byrd, 2001). It also offers structure and consistency in English language teaching (Canniveng \& Martinez, 2003); consequently, it helps in guiding the teaching and learning processes.

Furthermore, the textbook standardizes the English language teaching process (Richards, 2001). It is used in all schools in the same country; therefore, the same topics are taught in all schools to make sure that there is some degree of standardization (McGrath, 2002). The learners also receive similar content in all schools, so they are tested in the same way (Richards, 2001). The textbook organizes the education system across different schools within the country itself. Nevertheless, this might be considered as a barrier in restricting language learning development and teaching creatively as discussed further below. Another obstacle of standardization is that the textbook does not match all the needs and interests of the target learners (e.g. Bell \& Gower, 1998; Canniveng \& Martinez, 2003). However, such an argument presupposes the possibility of forecasting the needs of learners, and it overlooks the learners' common language needs (Crawford, 2002).

A further argument in favor of the use of the textbook is that it maintains the content quality (e.g. Bell \& Gower, 1998; Edge \& Wharton, 1998; Richards, 2001) because the learners use well-developed textbooks which have been tried and evaluated appropriately (Richards, 2001). The textbooks also promote learners' creativity, but there are possibly some constraints that affect the teachers' creativity (Bell \& Gower, 1998). Notably, teachers may be restricted to the allocated time, the exam formatting and/or the lack of professional development training.

The textbook also provides an input of linguistics and knowledge for teachers and learners (e.g., Ur, 1996; Crawford, 2002; McGrath, 2002; Canniveng \& Martinez, 2003; \& Timmis, Mukundan, \& Alkhaldi, 2009). Therefore, it can efficiently save their efforts and time (Richards, 2001). He maintains that the textbook provides skills and activities to the learners for learning and practice in an interactive environment. It also provides a linguistic link between teachers and learners to learn the target language (Canniveng \& Martinez, 2003) through 
the interaction among teachers, learners, and the content of the textbook (Crawford, 2002). Consequently, the textbook is useful as it includes the required language skills and activities to encourage the interactive learning (Timmis, Mukundan, \& Alkhaldi, 2009).

Moreover, the textbook is considered as an important resource for training teachers (e.g., Ur, 1996; Edge \& Wharton 1998; Mukundan, 2009). It contains language skills and teaching ideas (Richards, 2001). It includes the necessary support regarding the linguistics, teaching methodologies, and cultures (McGrath, 2002). This can be found in the textbooks or the teacher's guide. Such materials are useful resources for training the teachers by addressing their needs and expanding their teaching repertoire (Crawford, 2002). They may act as a de facto teacher training as they may be the only training resources that some teachers have (Timmis, Mukundan, \& Alkhaldi, 2009).

The textbook is useful for both experienced and inexperienced teachers (Edge \& Wharton, 1998). They maintain that the textbook, on the one hand, can provide the novice teachers with steps and activities that guide them practically to achieve the learning outcomes. On the other hand, teachers who have experience can quickly understand the textbook and its theoretical position, and they can critically assess it and use it. In other words, the textbook can encourage creativity in the teachers and learners if the embedded theories are well-developed in the activities coupled with professional development training on how to implement the activities critically and creatively.

Despite the fact that there are strong points advocating the use of textbooks for teaching language, there are some arguments against using them. For example, the textbook may restrict the teachers' creativity, particularly if they use it as the only source for teaching (e.g., Richards, 2001 \& Crawford, 2002). The teachers, for example, may follow the textbook as it is without any attempt to think independently, critically and creatively which might lead to learners' boredom and demotivation (Ur 1996).

To sum up, the textbook offers a comprehensive plan and useful input for the teaching and language learning process, and it provides opportunities for practice. It helps the learners to learn and practice English language. Learning is enhanced if the lesson is taught creatively. The textbook and its accompanying materials may also be good resources for training the teachers, especially novice teachers.

\section{Foreign Language Teachers}

The FL teacher's role is highly significant in the process of applying the language theories which are embedded in the activities. Their needs and teaching styles should be taken into consideration. McGrath (2002) indicates that the FL teachers do not generally have the option to select their textbooks on their own, so it is important to enable them to adopt a critical stance of the textbook that they will use for teaching the language. In other words, the teachers should be provided with professional development training on how to adapt the textbook and use it creatively.

Teachers can be involved in the textbook development process (Graves, 2000). Tomlinson (1998) argues that the teacher derives more benefits from the materials when they are not imposed; rather the teacher should feel free to engage with the materials as well as be involved in their own professional development and test out the materials. However, this may not be applicable in many countries as education is standardized in all schools, and the teachers are not allowed to develop their textbooks or language materials. Moreover, their teaching styles and needs may not be taken into consideration. The teachers, therefore, typically use published textbooks in which they have not been involved (Islam \& Mares, 2003). Timmis (2004) points out that the teachers' perspectives and abilities are important, so it is necessary to take them into account in the materials design process.

Unfortunately, many countries may not involve their teachers in the process of textbook selection, evaluation, and development. In fact, there should be professional training courses run by universities and/or Ministries of Education to enable the teachers to have the required skills on how to teach, evaluate, and develop their textbooks professionally (Alkhaldi, 2014, 2019b). Tomlinson (2015), for example, argues that the teacher must select materials which he thinks students will care about. Wright (2015) calls this role 'event marker'. By raising teachers' awareness as to the principles driving new learning experiences they can, in turn, create similar learning experiences for their students, thereby stimulating their creativity.

\section{Foreign Language Learners}

FL learners are one of the major components of the learning process. The textbooks are designed for them, and the teachers' training and experience are predicated upon acquiring the skills to help students learn the language effectively. Therefore, learners' levels, needs, interests, motivation and learning styles should always be taken into consideration. Textbooks and their accompanying materials should be designed based on the learners' needs such as their language learning problems, learning objectives, learning styles, etc. (Jolly \& Bolitho, 1998). The researchers of this study elaborated the following FL learners' variables:

- FL learners' interests, levels, and needs

- Learning styles

- Motivation 
- Teaching and learning approach

- Creativity

\subsection{FL Learners' Interests, Levels, and Needs}

It is important to make the content of the textbooks relevant to the learners' needs, levels, and interests. For example, McGrath (2002) argues that the needs should be "a reasonable good fit between the material, the learners (age, level and cultural background, including sophistication) and the constraints under which teaching takes place (length of course, course aims, official syllabus, public examination)" (p. 35). In other words, the learners' needs, interests, and levels should be emphasized by teachers and textbook writers (Tomlinson, 2003). Masuhara (1998) summarizes the learners' needs based on the related literature as the following:

- Personal needs: age; sex; cultural background; interest; educational background.

- Learning needs: learning styles; previous language learning experiences; gap between the target level and the present level in terms of knowledge e.g. target language and its culture; gap between the target level of proficiency in various competence areas (e.g. skills, strategies); learning goals and expectations for a course.

- Future professional needs: requirement for the future undertakings in terms of knowledge of language; knowledge of language use; L2 competence.

Other researchers discuss the needs in relation to the target language itself. Richards (2001), for example, indicates that identifying the needs is useful to know the learners' language skills that they need to perform roles effectively. He highlights the significant omission in the conceptualization of textbook design as made by curriculum planners; notably, they do not identify the needs of learners by asking learners. Needs are narrowly framed in terms of the language skills that the learner lacks at that level. Consequently, FL learners' needs are related to the language needs in an attempt to enable them to use English for education, business, research purposes, amongst other purposes. The FL teachers and textbook writers should also be aware of the leaners' language needs, personal needs, and learning.

\subsection{Learning Styles}

Learning styles are an important variable in the successful teaching and learning process (e.g. Tomlinson 1998, 2003; Oxford 2001; Richards 2001). The learning styles are used for finding the best ways for both students to learn effectively and teachers to teach efficiently (Gilakjani, 2012). Oxford (2001), for example, argues that learning styles can help in determining how the learners learn English. If the learners know their learning styles, they will be more focused and self-aware of how best they learn, which will aid their language learning (Gilakjani, 2012). As for the teacher, by knowing each learner's learning style they can adapt their teaching style to enhance learning.

Gilakjani (2012) describes how learners are either visual, auditory or kinaesthetic. Tomlinson (1998) specifies how the learning styles are evident in a language classroom: some learners may prefer seeing the language written down (visual learners), some learners may prefer hearing the language (auditory learners), some learners may prefer experiencing the language in large chunks (experiential learners ), some learners may prefer learning the language in discrete bits (analytic learners ), and other learners prefer physically to do things while they are experiencing the language itself (kinaesthetic learners).

Timmis, Mukundan, and Alkhaldi (2009) argue that the responsibility of adapting the materials to the learning styles is that of the teachers during the lesson. Gilakjani (2012) maintains that through this process, learners not only learn better but become more motivated and have a more positive attitude to learning. In other words, the teachers adapt the materials in accordance with the learning styles in the classroom to achieve the purpose of teaching and learning in a creative way.

\subsection{Motivation}

Motivation is the key to learn the FL creatively. Read (2015) argues that creative thinking arises from the emotional quality of learners' engagement in activities. Even if the textbooks are well- developed and the teachers are highly qualified, there will be no successful language learning if the learners are not motivated well. Motivation is significant in determining the preparedness of the learners to learn or communicate (e.g. Ellis, 1994; Ur, 1996; Arnold \& Brown, 1999). One definition of the term motivation is "the combination of effort plus desire to achieve the goal of learning the language plus favorable attitudes toward learning the language” (Nunan, 1999, pp.232-233). Ellis (1994) defines it as "the effort which learners put into learning an L2 as a result of their need or desire to learn it” (p.715). There are not any doubts about the significance of motivation in learning a FL (Arnold \& Brown, 1999). There are four common types of motivation which are related to English language learning as discussed by Ellis (1994) and Ur (1996):

1. Integrative motivation: The learners have the desire to identify with and integrate into the culture of the target language.

2. Instrumental motivation: The learners wish to learn the target language for studying or employment purposes.

3. Intrinsic motivation: The learners engage in learning the language for its own sake, and they may be interested in performing different tasks. 
4. Extrinsic motivation: it is derived from external incentives such as competitions, rewards (for success, tests or exams), etc.

The textbooks may involve the types of motivation, but it is in the hands of teachers on how to motivate their learners all the time using different techniques. Motivation is a key aspect for language learning, and it makes an important contribution to a FL learning (Dörnyei, 2001, 2009). The learners will not learn the language if they are not interested in their materials (Gilakjani, 2012).

Arnold and Brown (1999) state that "It should be noted that the affective side of learning is not in opposition to the cognitive side. When both are used together, the learning process can be constructed on a firmer foundation" (p.1). In other words, motivation is significant in affecting FL learners mentally and emotionally (Arnold, 1999), and they may achieve effective language learning if they are engaged in the learning process which may last for a long time without being forgotten easily.

\subsection{Teaching and Learning Approach}

It is beyond the scope of this study to discuss teaching and learning methods per se. The focus of this paper is on the creativity of language theories in use: creative language teaching and creative language learning taking the major components of successful language learning into consideration. The learner is the main factor to consider in the learning process. Some teachers may use the teacher-centered approach, thereby negating the agency and autonomy of the learners as they may be considered unqualified or inexperienced. Other instructors, however, may apply the learner-centered approach in the belief that it is effective for language learning.

Some teachers think that the 'student-centered' approach is superior to 'teacher-centered' approach (O'Neill 1991). The "learner-centeredness" term includes the educational philosophies which focus on the individual learner's needs, experience, self-reflection, awareness, learning strategies, critical thinking and other related skills and qualities which are important for learners to develop (Richards, 2001). Saraceni (2003), for example, argues that the textbooks should put the learners at the center of the learning process and let them provide the input. However, there is a disagreement about this because the 'learner-centered' techniques may be appropriate in some cases, but not in all cases (e.g., O'Neill, 1991). In other words, there should be a balanced technique for learner-centered approach and teacher-centered approach accordingly taking the learners' levels, needs, and interests into consideration towards creativity in language teaching and learning.

Based on the researchers' experience and related literature, there is no ideal method for teaching or learning English as a FL. For example, Mukundan (2009) indicates that very few situations of learning-teaching are alike, and there is no system which provides a textbook that is suitable to all situations because the cost of this would be too high. Consequently, some teachers may be advised to apply the Eclectic Approach with an emphasis on the FL learners as they are at the heart of the learning process. The Eclectic Approach is not in itself an approach, but it derives its sources from other approaches. Regardless of the approach, the teachers should have the flexibility to choose the approach that may fit a particular group to achieve the ultimate purpose of teaching and learning, notably effective language learning. Whichever approach is used, whether Communicative Approach, Direct Method or any other approach, the learners should always be in the minds of the teachers as they are the center of the learning process.

\subsection{Creativity}

Creativity cannot happen in a vacuum (Read, 2015). She maintains that there is something which stimulates the learners' original thinking. Creativity is a very important skill that all teachers and learners try to gain either in teaching or learning. Textbook writers also claim that their textbooks promote creativity through a wide range of activities that are based on many of the effective language teaching and learning theories and Second Language Acquisition (SLA) research findings.

Most linguists define the term creativity as something created for the first time or creating something different or outstanding (Alkhaldi, 2019a). Read (2015), for example, explains that creativity is thinking 'out of the box' and that learners try to come up with new solutions for any academic or even non-academic problems. Creating things for the first time is at the heart of creativity (Maley, 2015). He points out that "Creativity is widely believed to be about letting the imagination loose in an orgy of totally free self-expression. It is, of course, no such thing. Creativity is born of discipline and thrives in a context of constraints" (p.6).

In Tomlinson, Arnold, Bolitho, Ellis, Lutzker, Maley, Masuhara and Pugliese (2015), Tomlinson indicates that "creativity involves transcending the conventional norm. This could result in something universally unique or just in something which has never been done in that context before" ('What does creativity mean to me', para. 1). Lutzker explains that creativity will be developed appropriately only if it is practiced. In other words, creating things for the first time or in a different way is likely a good way to foster creativity in learning the language (Alkhaldi, 2019a). The interaction among textbooks (language theories and activities), teachers (teaching methods, teaching styles and professional development training), and learners (motivation, learning styles, experience, and creative ideas) complement each other and work closely together to promote creativity towards effective, durable learning. 
The activities of the textbook represent the language theories and SLA research findings. The textbook writers may prescribe techniques and methods on how to teach the activities in the teacher's guide, purportedly based on the results of SLA research (Alkhaldi, 2014). The learners respond to the teachers' instructions according to the previous prescribed methods. The learners may, nevertheless, still fail to achieve their learning goals because of the lack of creativity in such boring, routine teaching and learning. To be creative in teaching, the teachers should adapt their textbook, particularly the activities, teach them creatively or differently in accordance with their learners' needs, interests, levels, and learning styles (Benali, 2012). The learners should initiate their answers, responses, and/or ideas creatively and independently. Such a creative, interactive approach may foster creativity and achieve successful language learning for lifelong learning purposes.

\section{Creative Classroom Interaction}

Successful classroom interaction consists of three major factors, namely textbooks, teachers, and learners, as discussed earlier. To achieve creative interaction, all three factors and other related variables (learning styles, teaching styles, motivation, appropriate theories-activities, etc.) should carefully interact with each other in a friendly environment. Gilakjani (2012) advocates for an engaging and interactive classroom. Tomlinson (2015) argues that "the use of coursebooks could become more creative by replacing or modifying closed activities with open activities which encourage personal response to meaning, language discovery by the learners, authentic communication, taking risks, affective engagement, cognitive engagement, and being different” (p. 25).

Second language theories can be applied creatively in the language classroom environment, and the learners can use the language creatively if they have been provided with interesting, interactive, practical opportunities. Furthermore, the teachers provide their learners with theoretical background taking the learner-centered approach into consideration, and the learners apply the knowledge in an interactive learning environment. Wright (2015) argues that it is insufficient for a teacher to simply rely on innovative ways of using the materials. He maintains that active engagement methods should be used such as inviting students to do something challenging with the materials, elicit their contributions and show interest in their answers. In other words, if the interaction does not encourage critical and creative thinking abilities, the purposeful, durable learning may not be achieved. Combining all the aforementioned elements with different teaching methodologies that adapt to the teaching context and the needs of the students is a successful way to guarantee the engagement of the learners and enrich the teaching process (Benali, 2016) since it has been proven that there is no ideal teaching method that meets all learners' needs, levels, and interests.

\section{Conclusions}

Despite the existence of numerous obstacles to stimulating creativity in FL learners, such as the washback effect of external exams and rigid syllabus, it is nevertheless advantageous to enhance learners' creativity not only for language learning but also for developing other educational goals (Read, 2015). The creative use of language theories which are embedded in the textbooks can contribute to effective teaching and durable learning for current and future academic and employment purposes. Textbooks, teachers, and learners will create an effective learning environment to the extent that they are used interactively. The teaching context with all its elements and conditions reconciles the methodology. Hitherto, the successful teacher is the one who adapts to these conditions and achieves a harmonious environment that does not compromise teaching objectives or learners' needs. Being a creative teacher might sometimes mean to use unusual teaching methodologies to take the learners into a noteworthy learning experience or to simply shake their learning strategies with the aim of empowering their retrieval (Benali, 2019).

FL teachers should receive professional development training on how to use the language activities and theories effectively and how to motivate their learners to practice the language autonomously. Furthermore, they should have professional development training workshops on how to adapt textbooks creatively (Tomlinson, 2015). Consequently, successful language theories should be embedded in the textbook, well-taught by teachers, and well-learned by students through a creative, interactive environment. In other words, it is the responsibility of textbook writers, teachers, and learners to foster creativity and achieve effective language learning.

\section{REFERENCES}

[1] Abd Samad, A. (2003) Developing materials for the teaching of grammar. In J. Mukundan (Ed.), Readings on ELT Material (pp. 118- 127). Serdang: Universiti Putra Malaysia Press.

[2] Alkhaldi, A. A. (2019a). Once upon a time: A framework for developing creative writing in ESP and EAP. IJALEL, 8(4), 81-87.

[3] Alkhaldi, A. A. (2019b). Language materials observation: Professional development training. European Journal of Applied Linguistics Studies, 2(1), 164-174.

[4] Alkhaldi, A. A, (2014). Language theories donation through 
materials development. A case study in Jordan. IJALEL,3(3), 112-123.

[5] Alkhaldi, A. A. \& Oshchepkova, T. (2018). An analysis of English language theories: A case study. ALLS, 9(4), 227236.

[6] Alptekin, C. (2002). Towards intercultural communicative competence. ELT Journal, 56(1) 57-64.

[7] Arnold, J. ed. (1999). Affect in language learning. Cambridge: Cambridge University Press.

[8] Arnold, J. \& Brown, H. D. (1999). A map of the terrain. In J. Arnold (Ed.), Affect in language learning (pp.1-27). Cambridge: Cambridge University Press.

[9] Bell, J. \& Gower, R. (1998). Writing course materials for the world: a great compromise. In B. Tomlinson (Ed.), Materials development in language teaching (pp. 116-129). Cambridge: Cambridge University Press.

[10] Benali Taouis, H. (2019). What can wrong answers generate? Campos de Investigacion de Vanguardia. (pp.90-105). Madrid: Piramide del grupo ANAYA.

[11] Benali Taouis, H. (2016). Combining Teaching Approaches: A review of the literature and an example of possible combinations to encourage cooperative learning, Sciences du langage,10, 29-56.

[12] Benali Taouis, H. (2012). Group Work in Oral and Written Activities: An Interactive Approach to English Language Teaching. Germany: Lambert Academic Publishing.

[13] Canniveng, C. \& Martinez, M. (2003). Materials development and teacher training. In B. Tomlinson (Ed.), Developing materials for language teaching (pp. 479-489). London, Continuum Press.

[14] Cook, G. (2003) Applied Linguistics. Oxford: Oxford University Press.

[15] Crawford, J. (2002). The role of materials in the language classroom: Finding the balance. In J. Richards, \& W. Renandya (Eds.), Methodology in language teaching: An anthology of current practice (pp.80-90). Cambridge: Cambridge University Press.

[16] Dat, B. (2006). Developing EFL materials for local markets: Issues and considerations. In J. Mukundan, (Ed.), Focus on ELT materials (pp. 52-76). Petaling Jaya: Pearson Malaysia.

[17] Dörnyei, Z. (2001). Motivational strategies in the language classroom. Cambridge: Cambridge University Press.

[18] Dörnyei, Z. (2009). The L2 motivational self-system. In Z. Dörnyei \& E. Ushioda (Eds.), Motivation, language identity and the L2 self (pp. 9-42). Bristol: Multilingual Matters.

[19] Edge, J. \& Wharton, S. (1998). Autonomy and development: living in the materials world. In B. Tomlinson (Ed.), Materials development in language teaching (pp. 295-310). Cambridge: Cambridge University Press.

[20] Ellis, R (1994). The study of second language acquisition. Oxford: Oxford University Press.

[21] Gilakjani, A. P. (2012). Visual, auditory, kinaesthetic learning styles and their impacts on English language teaching. Journal of Studies in Education, 2(1) 104-113.
[22] Graves, K. (2000). Designing language course: A guide for teachers. Boston: Heinle \& Heinle.

[23] Hann, N.B., Timmis, I., Alkhaldi, A., Yi, Y. \& Rico, C.T. (2014). Impact of English on learners' wider lives. British Council. The article is available at https://www.teachingenglish.org.uk/article/impact-glishlear ners\%E2\%80\%99-wider-lives

[24] Islam, C. \& Mares C. (2003). Adapting classroom materials. In B. Tomlinson (Ed.), Materials Development for language teaching (pp. 86-100). London: Continuum Press.

[25] Jolly, D. \& Bolitho, R. (1998). A framework for writing materials. In B. Tomlinson (Ed.), Materials development in language teaching (pp. 90-115). Cambridge: Cambridge University Press.

[26] Maley, A. (2015). Overview: Creativity - the what, the why and the how. In A. Maley \& N. Peachey (Eds.), Creativity in the English language classroom (pp. 6-13). London: British Council.

[27] Masuhara, H. (1998). What do teachers really want from coursebooks? In B. Tomlinson (Ed.), Materials development in language teaching (pp. 239-260). Cambridge: Cambridge University Press.

[28] Mckay, S. (2002). Teaching English as an international language: Rethinking goals and approaches. Oxford: Oxford University Press.

[29] McGrath, I. (2002). Materials evaluation and design for language teaching. Edinburgh: Edinburgh University Press.

[30] Mukundan, J. (2006). Are three new ways of evaluating ELT textbooks? In J. Mukundan (Ed.), Readings on ELT materials II (pp. 170-180). Petaling Jaya: Pearson Malaysia.

[31] Mukundan, J. (2009). ESL textbook evaluation: A composite framework. Germany: Lambert Academic Publishing AG and Co. KG.

[32] Nunan, D. (1999). Second language teaching and learning. Boston: Heinle \& Heinle.

[33] O'Neill, R. (1991). The plausible myth of learner-centeredness: Or the importance of doing ordinary things well. ELT Journal, 45(14), 293-304.

[34] Oxford, R. L. (2001). Language learning styles and strategies. In M. Celce-Murcia (Ed.), Teaching English as second or foreign language ( $3^{\text {rd }} \mathrm{ed}$, pp. 359-366). Boston: Heinle \& Heinle.

[35] Read, C. (2015). Seven pillars of creativity in primary ELT. In A. Maley \& N. Peachey (Eds.), Creativity in the English language classroom (pp. 29-36). London: British Council.

[36] Richards, J. (2001). Curriculum development in language education. Cambridge: Cambridge University Press.

[37] Saraceni, C. (2003). Adapting courses: A critical view. In B. Tomlinson (Ed.), Materials development for language teaching (pp. 72-85). London: Continuum Press.

[38] Timmis, I. (2004). Materials design principled compromise and compromised principles? Folio, 9(1) pp.11-14.

[39] Timmis, I., Mukundan, J., \& Alkhaldi A. A. (2009). Coursebooks: soft or fair targets? Folio, 13(2) pp.11-13. 
[40] Tomlinson, B. (Ed.). (1998.). Materials development in language teaching. Cambridge: Cambridge University Press.

[41] Tomlinson, B. (Ed.). (2003). Materials development for language teaching. London: Continuum Press.

[42] Tomlinson, B. (2015). Challenging teachers to use their coursebook creatively. In A. Maley \& N. Peachey (Eds.), Creativity in the English language classroom (pp. 24- 28). London: British Council.

[43] Tomlinson, B \& Masuhara, H (2013). Adult coursebooks. ELT Journal, 67(2) 233-249.

[44] Tomlinson, B. Arnold, J., Bolitho, R., Ellis, R., Lutzker, P.
Maley, A., Masuhara, H., \& Pugliese, C. (2015). Creativity for change in language education. Humanising Language Teaching, 17 (2), available at http://old.hltmag.co.uk/apr15/ mart02.htm

[45] Ur, P. (1996). A course in language teaching: Practice and theory. Cambridge: Cambridge University Press.

[46] Wala, D. A. S. (2003). A coursebook is what it is because of what it has to do: An editor's perspectives. In B. Tomlinson, (Ed.), Materials development for language teaching. London: Continuum Press, pp. 58-71.

[47] Wright, A. (2015). Medium: Companion or slave? In A. Maley \& N. Peachey (Eds.), Creativity in the English language classroom (pp. 14-23). London: British Council. 